沿岸から東へ, トルキスタン, ネパール，ヒマ ラヤ地方, 中国北部中部, モンゴル, ソ連の南 部, 沿海州, 朝鮮半島, 日本）に分布する.

Deinagkistrodon 属は 1 taxon で台湾, 中国南 部などに分布する. Calloselasma 属も 1 taxon でタイ, ベトナム, ジャワなどに分布し, Hypnale 属は 3 taxa よりなり, スリランカ, ジャ ワ西南部などに分布している.

本書の構成の概要は序, Agkistrodon 属の分 類学的地位, 照合表及び検索表, 属の特性, 新 大陸の各 taxon, 旧大陸の各 taxon, と続く. 各々の taxon については学名, 同物異名, 模式 標本, 模式産地, 俗名, 特徵, 鱗式, 半陰茎, 色彩と斑紋, 体形と体長, 分布, 測定した標本 番号, 生活史と生態, などの順に述べられてい る. 各論の最後に, 全般の要旨, 引用文献, 原 色図版32枚, 黒白図版20枚と続く.その他, 本 文中に分布図, 挿図など多数が用いられている. さらに本書の末尾には補助論文としてマムシ属 に関連する 9 編がそれぞれの専門学者により寄 稿されている. それらは儀式的行動, 染色体, 北米の化石, 旧大陸の種, 蛇毒関係の文献, 頭 骨 - 骨格及び筋肉, 半陰茎, 抗体学的関係, 米 国東部の先史時代の森林とマムシ，である.

さて, 本書を見る. 序には本書の来歴, 用語 の解説が詳しい, また11枚の一覧表には各 taxon の腹鱗数, 尾下鱗数, 等々がまとめてあり 大変便利である. 序の末尾には7頁にわたる謝 辞がある. 各 taxon の分類学的記載は多くの資 料がよくまとめてある．調査した標本数の多い のに驚く. 分布図には標本で確認した地点と文 献からの地点が明瞭に区別して記載されてい る. 中国やソ連の地名の一部についてはその場 所の特定に大変苦労された由である. 各論の taxon の記述で分量の最も多いのは A. contortrix mokasen で29頁. 日本のマムシ $A . b$. blomhoffii は14頁で, 民間伝承のッチノコも挿 図入りで紹介されている. 各 taxon の生活史 及び生態の項には，それぞれ多くの文献の内容 が詳細に紹介されている.

なお，本書は第 1 回世界爬虫両棲類学会議 (First World Congress of Herpetology) の記念図 書として SSAR から出版されたものである.
深田 祝

（605 京都市東山区泉涌寺山内町1-7）

\section{The snakes of Iran. By Mahmoud Latifi.}

164ページ，カラープレート24枚, 地図 2 枚, figure 25枚, 1991年 3 月発行. US\$22.00.

1985年発行ペルシア語原典の英訳で，イラン のへビ全種を扱った唯一の単行本. 著者はテへ ランにある Razi Institute の Department of Herpetology and Antivenom Studies $の$ 所長. 英 訳監修は Alan E. Leviton 及び George R. Zug. ヘビ一般の生態, へビ毒, へビ咬傷とその治療 法の他にイラン産へビ全種の大きさ, 獲物, 繁 殖, 生息環境, 分布を記載. 検索表と詳細な参 考文献目録もある. 英訳の付録には補助参考文 献や原典の学名と最新の学名の対照表もある.

Herpetofauna of Iraq, Kuwait and the Arabian gulf region. By Alan E. Leviton, Steven $C$. Anderson, Sherman A. Minton, and Kraig Adler.

175ページ，カラープレート16枚（写真90枚 を含む), 地図及び figure も多数. 1991年 6 月 発行予定. US\$28.00.

イラク, クウェート, サウジアラビア北部と 東部, ペルシア湾, イラン南西部, バーレーン, カタール，アラブ首長国連邦に分布する爬虫両 生類を同定するためのハンドブックで, 144 種 ・亜種の checklist となっている.カラープレー トには checklist に取り上げている各属の主な 種, 毒へビのすべての種の写真がある. また毒 ヘビについては各種の形態, 生態, 行動などが 細かく書かれ, 毒へビ咬傷の応急手当, 治療法, 抗毒血清の種類と入手先も記載されている. 巻 末に中近東の爬虫類学の参考文献と John E. Simmons による採集法や固定方法についての 付録がある。

上記 2 書の注文先 : Dr. Robert D. Aldridge, Department of Biology, St. Louis University, St. Louis, Missouri 63103, USA.

R. C. ゴリス （216 川崎市官前区初山1-7-13） 